\title{
Pharmacist professionals in the prevention of drug abuse: updating roles, and opportunities
}

\author{
Gabriela Arantes Wagner1,*, Arthur Guerra de Andrade² \\ ${ }^{1}$ Department of Psychiatry, Medical School, University of Sao Paulo, ${ }^{2}$ Department of Psychiatry, ABC Medical School
}

\begin{abstract}
The objective of this paper was to prepare and provide resources to pharmacists and other healthcare professionals, enabling them to carry out a critical analysis on drug abuse, acquiring knowledge in several areas that effectively contribute to their personal development in this professional field. Professionals play a crucial role in the reduction and prevention of substances abuse, since they are able to advise patient about illicit drugs, psychotropic medicines and alcohol abuse. There is an urgent need to specialize pharmacists to act in the national public health service and contribute to actions aimed at the surrounding community.
\end{abstract}

Uniterms: Pharmaceutical professional. Drugs/abuse. Drugs/dependence. Public health.

\begin{abstract}
Esse artigo tem o intuito de preparar e fornecer subsídios a farmacêuticos e outros profissionais de saúde a realizarem uma análise crítica sobre o abuso de drogas adquirindo conhecimento em diversas áreas que contribuam para o seu próprio desenvolvimento nesse campo de atuação. O profissional é fundamental na redução e prevenção ao abuso de substâncias, pois é capaz de aconselhar pacientes sobre o abuso de drogas ilícitas, medicamentos psicotrópicos e álcool. Há urgência na especialização de farmacêuticos para atuarem na saúde pública nacional contribuindo nas ações dirigidas à comunidade.
\end{abstract}

Unitermos: Profissional farmacêutico. Drogas/abuso. Drogas/dependência. Saúde pública.

\section{INTRODUCTION}

Despite scientific advances and continuous creation of novel clinical methods, the complex problem of drug abuse and dependence is growing. It is not possible to determine if an individual will become drug dependent, and the consumption of psychoactive substances among youths and adults from all economic backgrounds is prevalent.

In Brazil, problems related to psychoactive substance consumption are a major concern, a fact demonstrated by transversal epidemiologic studies conducted at elementary or grade school, high school and higher education institutions in Brazil. The information about drug use in a given population assists and defines the type of intervention that should be developed. In order to implement such actions, there is a need for specific knowledge about the evolution of use of given substances within particular settings, as well as working descriptions of current pre-

*Correspondence: G. A Wagner. PROGREA-IPQ-FMUSP, Departamento de Psiquiatria, Faculdade de Medicina, Universidade de São Paulo - FMUSP. Rua Dr. Ovidio Pires de Campos, n 785 - 05403-010 - São Paulo - São Paulo, Brasil. E-mail: gabrielaaw@usp.br vention programs in place (Andrade et al., 1997, Galduróz et al., 2005, Stempliuk et al., 2005, Carlini et al. 2006, SENAD, 2007).

According to data published in the "World Drugs Report' of 2007, issued by the United Nations Organization (UNO), cocaine use in Brazil increased from $0.4 \%$ (in 2001 ) to $0.7 \%$ (in 2005) while marijuana use also increased. Marijuana was the illicit drug presenting the highest increase in use over recent years, having risen from $1 \%$ in 2001 to $2.6 \%$ in 2005 . The UNO considers this rise a reflection of the drug's availability in Brazil (WDR, 2007).

An effective policy can act to reduce problems related to alcohol and other drugs consumption experienced by a given society. To this end, the "Policy of the Ministry of Health for Integral Care of Alcohol and Other Drugs Users" in which it "assumes integrally and articulately the challenge to prevent, treat and rehabilitate users of alcohol and other drugs, as a public health problem" (Brasil, 2004) requires the creation, at a national level, of multidisciplinary health teams to intervene in the healthdisease process of dependents. (Machado, Miranda, 2007).

In Brazil, no previous studies have investigated 
pharmacists' conditions or qualifications to tackle drug abuse and dependence (Pepe, Castro, 2000). The preamble of the 'Code of Ethics for the Pharmacist Profession' elucidates the necessity of knowledge and actions from this professional in all public health fields, when stating "The pharmacist is a healthcare professional, charged with performing activities inherent to the pharmaceutical professional sphere, so as to safeguard public health, including the provision of educational actions aimed at the local community for health promotion purposes" (Conselho Federal de Farmácia, 2004).

In this context, the qualification of healthcare professionals is essential to enable them to act in the spheres of prevention and treatment. With regard to pharmacists, this need has been demonstrated in some international studies, mainly citing the Pharmacy practice and teaching about substance abuse (Busto et al., 1994; Dole, Tommasello, 2002; Tommasello, 2004).

These previous studies have revealed that pharmacists receive scant information on substance abuse during their undergraduate courses, and few professionals from this area can be considered experts on the subject. In addition, the results demonstrate that the role of this professional in reducing and preventing substance abuse could lie in the pharmacist-patient interaction during psychotropic medication dispensation (Fleming et al., 2001; Grahan et al., 1999; Roberts, Hunter, 2004).

For these professionals, to attain an understanding of the different biochemical mechanisms of action associated to all complex psychosocial concepts generally involved in the development of dependence as a disease is a stimulating challenge. In the undergraduate course of Pharmacy, as naturally expected, the biochemical, toxicological and pharmacological knowledge is focused on other areas, while psychosocial issues are given secondary importance. This article seeks to prepare pharmacists to cope with situations in which the presence of dependent individuals occurs, and to update pharmacists, as well as other healthcare professionals interested in this theme by providing guidance to professionals on critical analyses about drug abuse, and on acquiring knowledge in several areas that can effectively contribute to their personal development in this field of activity.

\section{Basic concepts of drug abuse and dependence}

Dependence is defined as a chronic brain disease (AMERICAN PSYCHATRIC ASSOCIATION, 1994) characterized by the search and compulsive use (inability to resist drug cravings) of a given substance, for which the individual despises the effect or adverse events produced by its consumption. Dependence is considered a brain disease because, generally, the consumed drugs act on the Central Nervous System (CNS) altering its functioning with respect to cerebral structures and activity (Koob et al., 2004). These changes can persist and lead to dangerous behaviors or loss of control (O'Brien, 2006; NIDA, 2007; Moreau, 2008).

Some variables act simultaneously in the sense of effectively influencing the probability of an individual becoming drug dependent or simply of abusing a given drug. These variables can be divided into: agent (drug); host (user) and environment. How, or the way in which, an individual becomes dependent, is related to their personal vulnerability. Generally, a number of risk factors are associated to the development of this disease, such as drug availability, its cost, administration route, toxicokinetics and dynamics, heredity, innate tolerance, speed of development of acquired tolerance, mental disturbances, social status, group pressure, primary and secondary reinforcement, and conditioned stimulations (O'Brien, 2006; NIDA, 2007; Moreau, 2008).

The tolerance and abstinence syndrome are very important symptoms to diagnose drug dependence. However, these are not the sole symptoms to characterize the condition (Moreau, 2008). Tolerance is the most common response to repeated use of a single drug and can be defined as a decrease in response to the drug, after prolonged administration, that is, the individual requires a higher drug dose to obtain the same effect previously experienced. The abstinence syndrome is a combination of signs and symptoms occurring upon sudden discontinuation of drug use. These signs are physical and may occur due to two main factors: use interruption or CNS hyperactivity resulting from readaptation to the drug causing the dependence (O'Brien, 2006; NIDA, 2007).

Another very important concept related to drug abuse is the reinforcement potential. This is defined as the capacity a drug possesses to generate repeated selfadministration without requiring other external induction mechanisms. Some drugs possess higher or lower positive reinforcements and, without doubt, those providing most pleasant and faster rewards are most reinforced because they stimulate self-administration more intensely (Moreau, 2008).

There are several types of abuse drugs. In Brazil, there are licit (or legal) drugs, such as alcohol, tobacco and psychotropic medications, as well as illicit (illegal) drugs, such as marijuana, cocaine, ecstasy, crack and LSD. These drugs do not act on the CNS in the same way. Each drug possesses specific mechanisms of action and interactions, as evidenced in Table I. 
TABLE I - Drug classification and the main characteristics that should be known by the pharmacist professional and other health care professionals. (NIDA, 2007; Almeida, Lima, 2008; Cazenave, Costa, 2008; Chasin, Silva, Carvalho, 2008; Galvão, Galvão, Moreau, 2008; Moreau, 2008; Oliveira, Camargo, 2008; Scivoletto, Malbergier, Pileggi, 2008)

\begin{tabular}{|c|c|c|c|c|c|c|c|}
\hline Drug & Classification & Licit/illicit & $\begin{array}{c}\text { Administration } \\
\text { path }\end{array}$ & Mechanism of action & Effects & $\begin{array}{c}\text { Reinforcement } \\
\text { potential }\end{array}$ & $\begin{array}{l}\text { Does it cause } \\
\text { dependence? }\end{array}$ \\
\hline Heroin & Opiate & Illicit & $\begin{array}{l}\text { Intravenous, } \\
\text { nasal or inhaled }\end{array}$ & $\begin{array}{l}\text { Interaction between the } \\
\text { drug and endogenous } \\
\text { opioid receptors }\end{array}$ & $\begin{array}{l}\text { Supraspinal analgesia, } \\
\text { respiratory depression, } \\
\text { euphoria and myosis }\end{array}$ & High & Yes \\
\hline Cocaine & Stimulant & Illicit & $\begin{array}{l}\text { Intravenous and } \\
\text { nasal (powder) } \\
\text { or inhaled } \\
\text { (crack) }\end{array}$ & $\begin{array}{l}\text { Transient elevation } \\
\text { of concentrations } \\
\text { of Norepinephrine } \\
\text { and Dopamine with } \\
\text { subsequent decrease to } \\
\text { values below normal } \\
\text { range }\end{array}$ & $\begin{array}{l}\text { Reactivity, humor, emotion } \\
\text { and stereotyped behavior, } \\
\text { tachycardia and mydriasis. } \\
\text { Euphoria followed by } \\
\text { depression }\end{array}$ & High & Yes \\
\hline Amphetamines & Stimulant & $\begin{array}{c}\text { Illicit (MDA } \\
\text { ecstasy, rebites) and } \\
\text { licit (anorexigen } \\
\text { regulated by } \\
\text { Ordinance \# } \\
344 / 98 \text { ) }\end{array}$ & Oral & $\begin{array}{l}\text { Act as sympathomimetic } \\
\text { amines in the a and b } \\
\text { adrenergic receptors }\end{array}$ & $\begin{array}{l}\text { Agitation, irritability, } \\
\text { insomnia, trembling, } \\
\text { diaphoresis, tachycardia, } \\
\text { mydriasis and redness. }\end{array}$ & High & Yes \\
\hline $\begin{array}{c}\text { Marijuana }(\Delta-9 \\
\text { THC })\end{array}$ & Cannabis & $\begin{array}{l}\text { Illicit (marijuana, } \\
\text { skank, hashish) }\end{array}$ & Inhaled & $\begin{array}{c}\text { Interaction of } \Delta-9 \\
\text { THC with cannabinoid } \\
\text { and endocannabinoid } \\
\text { receptors (CB1 and } \\
\text { CB2). Their euphoric } \\
\text { and dependence producer } \\
\text { mechanisms are still very } \\
\text { little known. }\end{array}$ & $\begin{array}{l}\text { Euphoria, followed by } \\
\text { relaxation, somnolence or } \\
\text { depression, loss of time } \\
\text { and space discrimination } \\
\text { and decreased motor } \\
\text { coordination. Tachycardia, } \\
\text { red eyes, appetite increase } \\
\text { ("larica") and mouth } \\
\text { dryness }\end{array}$ & High & $\begin{array}{l}\text { The prolonged } \\
\text { use could lead } \\
\text { the dependence, } \\
\text { but there are } \\
\text { controversies in the } \\
\text { diagnostic criteria } \\
\text { of disease (DSM } \\
\text { IV) }\end{array}$ \\
\hline $\begin{array}{l}\text { Ethanol } \\
\text { (alcoholic } \\
\text { beverages) }\end{array}$ & Depressor & Licit & Oral (intake) & $\begin{array}{l}\text { Increases the synaptic } \\
\text { inhibition mediated } \\
\text { by GABA and by } \\
\text { chloride flux. Acts in } \\
\text { other neurotransmitter } \\
\text { systems, such as } \\
\text { adrenergic and opioid } \\
\text { systems, in the release of } \\
\text { serotonin, acetylcholine, } \\
\text { glutamate and calcium }\end{array}$ & $\begin{array}{c}\text { Sedation, anxiety decrease, } \\
\text { doughy speech, ataxia, } \\
\text { judging ability and } \\
\text { behavioral disinhibition. }\end{array}$ & High & Yes \\
\hline Nicotine & Tobacco & Licit & Inhaled & $\begin{array}{l}\text { Agonist of nicotinic } \\
\text { receptor of acetylcholine } \\
\text { in the peripheral and } \\
\text { central nervous system }\end{array}$ & $\begin{array}{l}\text { Central and motor } \\
\text { stimulation, cardiac } \\
\text { frequency and blood } \\
\text { pressure elevation. }\end{array}$ & $\begin{array}{l}\text { Lower than that } \\
\text { of cocaine and } \\
\text { amphetamines }\end{array}$ & Yes \\
\hline LSD & Hallucinogenic & Illicit & Oral & $\begin{array}{l}\text { Specific stimulation } \\
\text { of serotonin receptors } \\
\text { 5-HT1 and 5HT-2 }\end{array}$ & $\begin{array}{l}\text { Hallucinations, physical, } \\
\text { time, space sensation and } \\
\text { affective modifications. }\end{array}$ & High & Yes \\
\hline Ecstasy & Hallucinogenic & Illicit & Oral & $\begin{array}{c}\text { Increases the } \\
\text { liberation of at least } \\
3 \text { neurotransmitters } \\
\text { in the synaptic cleft: } \\
\text { serotonin, dopamine and } \\
\text { noradrenalin }\end{array}$ & $\begin{array}{l}\text { Increase of euphoria and } \\
\text { well-being; sharpened } \\
\text { sensorial perception, } \\
\text { improved sociability, } \\
\text { increase of intimacy } \\
\text { sensation and proximity to } \\
\text { other people. }\end{array}$ & High & Yes \\
\hline Barbiturics & Depressor & $\begin{array}{l}\text { Licit (regulated } \\
\text { by Ordinance \# } \\
344 / 98)\end{array}$ & $\begin{array}{l}\text { Oral (hypnotic } \\
\text { and sedative) } \\
\text { Intravenous } \\
\text { (induction or } \\
\text { maintenance } \\
\text { of anesthesia } \\
\text { or epilepsy } \\
\text { treatment) } \\
\end{array}$ & $\begin{array}{l}\text { Strengthening of GABA } \\
\text { action in the pre- and } \\
\text { post-synaptic GABA } \\
\text { receptor }\end{array}$ & $\begin{array}{l}\text { Depression, light sedation } \\
\text { and hypnosis to deep coma. }\end{array}$ & High & Yes \\
\hline Benzodiazepines & Depressor & $\begin{array}{l}\text { Licit (regulated } \\
\text { by Ordinance \# } \\
344 / 98)\end{array}$ & Oral & $\begin{array}{l}\text { Interaction with Central } \\
\text { Nervous System } \\
\text { receptors placed in } \\
\text { parallel to GABA } \\
\text { receptors, strengthening } \\
\text { the activity of this } \\
\text { neurotransmitter. }\end{array}$ & Depression & High & Yes \\
\hline
\end{tabular}




\section{National epidemiologic studies}

The epidemiologic studies about drugs seek to: (i) ascertain the use of given drugs in a population of interest, (ii) determine the factors influencing such use, and (iii) study the actual impact of actions proposed to prevent their use. These surveys possess direct influence in the devising, creation and implementation of national public policies. In Brazil, the majority of epidemiologic studies consist of prevalence studies, that is, the proportion of cases over a given time, in a specific population.

These studies are generally promoted by the organs responsible for their development, which are universities or entities linked to university research groups and official government organs. Some of these studies are disseminated by the National Antidrug Secretariat (Secretaria Nacional Antidrogas - SENAD) on its Internet gateway (www.senad.gov.br), or in the form of scientific articles (Carlini-Contrim, Gazal-Carvalho, Gouveia, 2004; Galduróz et al., 2005; Carlini, 2006).

Numbering among the most important of these initiatives are the studies run by the Brazilian Center for Information on Psychotropic Drugs (Centro Brasileiro de Informações sobre Drogas Psicotrópicas - CEBRID), SENAD and the University of São Paulo (USP). In the II National Survey on Psychotropic Drug Use in Brazil, run in 2005 by CEBRID, several conclusions are relevant to healthcare professionals. Briefly, the prevalence of in-life use of any drug, except for tobacco and alcohol, had the highest rates in the Northwestern region, where $27.6 \%$ of interviewees had previously used drugs. The region with lowest in-life* use was the Northern region, with 14.4\% drug use. In Brazil overall, the in-life use for any drug (except tobacco and alcohol) was $22.8 \%$. This percentage is very similar to that reported for Chile (23.4\%) and is almost half the rate found in North America (USA) (45.8\%) (Carlini, 2006).

With respect to Brazilian college students, the most relevant studies are concentrated at the University of São Paulo, where the evaluation of drugs consumption prevalence had previously taken place in 1996 and 2001. The comparison of these studies between the two periods revealed considerable changes in the behavior for and consumption of psychoactive substances. The patterns of use became more diversified with a significant increase in the in-life consumption of alcoholic beverages (from $88.5 \%$ to $91.9 \%$ ), tobacco (from $42.8 \%$ to $50.5 \%$ ), marijuana (from 31.3 to $35.3 \%$ ) and hallucinogenic agents (from $6.1 \%$ to $11.4 \%$ )(Andrade et al., 1997; Stempliuk et al., 2005). Female students began consuming more to- bacco, marijuana, anticholinergic agents, inhaling agents and continued to be the highest consumers of tranquilizer drugs and amphetamines (Wagner et al., 2007; Wagner, Andrade, 2008).

In 2007, the National Antidrug Secretariat (SENAD) published a report evaluating alcohol consumption in the Brazilian population. This study found that the regular use of alcoholic beverages by teenagers starts at 14.8 years of age, and by young adults at 17.3 years of age. These figures were obtained after filtering out young adults that had began consumption after 18 years old, that is, thus pointing to a decrease in the average age that young Brazilian adults start alcohol consumption (SENAD, 2007).

Epidemiologic studies are useful in characterizing the profile of a given population. The knowledge of this aspect, for the pharmacist professional, helps in the decision taking regarding the development of a prevention program in their community, or in their catchment region.

\section{Brazilian legislation and health policies on drugs}

The Brazilian Legislation on Drugs has changed in recent years. Law No. 6368, in force since 1976, was superseded by Law \# 11343, of August $23^{\text {rd }}, 2006$, which contained important modifications with respect to illicit drugs users, their treatment and criminalization. Law No. $6368 / 76$ favored the consolidation and amplification of the powers of institutional juridical apparatus in order to control drug use and trafficking, by means of the creation of relevant institutional spaces in the field of healthcare and Justice, such as the creation of treatment centers (Brasil, 2006).

Law No. 11343, of August $23^{\text {rd }}, 2006$, instituted the National System of Public Policies on Drugs (Sistema Nacional de Políticas Públicas sobre Drogas - SISNAD), prescribing measures of prevention, attention and social reinsertion of drug users and dependents, and maintaining the function of defining crimes related to trafficking and unauthorized production of illicit drugs. In the SISNAD, the National Antidrug Secretariat (SENAD) is the executive organ responsible for health actions aimed at drugs dependents, whereas the health sector, the Unified Health System (Sistema Único de Saúde-SUS) is the entity responsible for provision of integral health care assistance to all Brazilian citizens, including drug dependents (Brasil, 2004, 2006).

Under SUS, the assistance to alcohol and drugs users is formed by a network of integral healthcare assistance to patients, with activities related to prevention, health promotion and protection, besides networks formed by specialized entities, known as Centers for Psychosocial 
Assistance "alcohol and drugs" (Centros de Atenção Psicossocial "álcool e drogas" - CAPSad), and non-specialized organs (basic health units, family health programs and hospitals) (Machado, Miranda, 2007).

With regard to the National Agency of Health Surveillance, one of its goals is to protect the health of the general population, as well as to uphold its legal attributions. To this end, Ordinance No. 344, of May $12^{\text {th }}$ was created with the purpose of monitoring and supervising the sale of products and medications subject to special control (Brasil, 1998). This ordinance was improved in 2007, with the creation of the National System of Management of Controlled Products, according to Resolution No. 27, of March $30^{\text {th }}, 2007$, which "considers the necessity to disseminate information, in its diverse levels of detail, with respect to commerce and use of substances and medications subject to special control for opportune decision taking of the appropriate authorities in the ambit of the National System of Health Surveillance" (Brasil, 2007). In this ordinance, there are lists of medications and substances subject to control, including psychotropic medications, narcotics and precursors in the production of abused drugs, such as organic solvents (Brasil, 1998).

\section{Professional performance}

In Brazil, the governmental initiatives for the reformulation of the university curriculum for future pharmacist professionals, does not encompass the inclusion of themes such as substances abuse, dependence and preventive actions. There is no such study or focus on drug abuse on Brazilian undergraduate courses.

Generally, these themes are addressed in discussions of the different disciplines, such as Public Health and Toxicology. Pharmacists interested in the subject are obliged to pursue graduate courses in areas other than their own (Psychiatry, Psychobiology, Psychology, etc.) in order to act as agents multiplying information on the theme. Differentiated from the national curriculum, The American Association of Colleges of Pharmacy has made mandatory the implementation of a study guide for pharmacists on drugs dependence and abuse in 1991, in order to bring these professionals closer to the reality on drugs (Dole, Tommasello, 2002).

In this context, we sought to describe the ideal role of pharmacists and the forms of activity in different areas of drug abuse and dependence.

\section{Prevention}

The prevention of drugs use entails interventions aimed at decreasing the probability of occurrence of health problems associated to drugs consumption. According to the World Health Organization (WHO), interventions related to prevention of drugs use are characterized into three levels: primary, secondary and tertiary (WHO, 1992).

In primary prevention, there is a conjunction of actions intended to prevent drugs use, aimed at lowering the chance of further individuals starting to use drugs. In secondary prevention, there is a conjunction of actions intended to prevent the occurrence of complications in occasional users. These measures seek to identify the users and promote changes in their behavior. In tertiary prevention, the focus is on those who make abusive use of drugs. These actions seek to prevent additional loss and/or to reintegrate individuals presenting more serious problems into society (WHO, 1992).

In view of the existence of several models of prevention, it is fitting to emphasize that the most important criterion to choose the most adequate intervention in each circumstance and context, is previous knowledge on, and respect for, the characteristics of the communities within which the initiative is intended to act. The strategies for damage reduction are deployed in this context, because besides being present at the tertiary level of prevention for instance, when providing new syringes and needles to dependent patients infected with HIV, they also affect the primary and secondary levels, when promoting strategies of 'anti drink driving' or when informing young students regarding the importance of use of condoms after alcohol and drugs consumption at parties.

According to Dole and Tomasello (2002), there are several forms of action of the pharmacist professional in the prevention of drug abuse, in roles under the three models determined by WHO. When trained, the pharmacists are healthcare professionals whom, by means of direct contact with the patient are able to: assist in dependence or abuse diagnosis, making use of interview instruments; create for instance, a list of programs of dependence treatment in their neighborhood or work place; create in their community, a support group for patients harboring the disease, intervening directly with these patients through motivational interviews or as multiplier agents of prevention and, mainly, participating in multidisciplinary health teams assisting these patients and taking information to their families about drugs and their respective harmful effects. (Dole, Tommasello, 2002).

\section{Treatment}

Majority of the studies and investigations on pharmacist professional actions to combat psychoactive substances abuse and dependence are related to pharmaceutical care provided to patients making use of medications 
TABLE II - Types of prevention and strategies (OMS, 1992).

\begin{tabular}{ll}
\hline Prevention & Strategies \\
\hline Primary & $\begin{array}{l}\text { Divulgence of information, sportive and cultural } \\
\text { activities, change of environmental behavior } \\
\text { inhibiting experimentation. }\end{array}$ \\
Secondary & $\begin{array}{l}\text { Learning of new attitudes and more responsible } \\
\text { behaviors. }\end{array}$ \\
Tertiary & $\begin{array}{l}\text { Treatment of Abstinence Syndrome, treatment of } \\
\text { overdoses, hospital attendance of intoxications, } \\
\text { forwarding and follow-up of dependents families } \\
\text { and help for social rehabilitation of dependents. }\end{array}$ \\
\hline
\end{tabular}

for treatment of compulsion (for instance, methadone, bupropion, naltrexone, benzodiazepines) (Pepe, Castro, 2000; Fleming et al., 2001; Carlini, Nappo, 2003; Roberts, Hunter, 2004; Tommasello, 2004). In these studies, the pharmacist is a professional possessing a privileged position to provide information about drug abuse and dependence to other professionals of multidisciplinary health teams (Pepe, Castro, 2000; Fleming et al., 2001; Roberts, Hunter, 2004).

As previously outlined, dependence is a chronic brain disease requiring treatment and follow-up, for the rest of the life of the affected individual. Treatment of dependence generally involves a combination of therapies:

- Medication therapy: Use of some classes of medications in different phases of the disease, aiming to help the patient to stop drug consumption, to remain in treatment and to prevent recurrence. The role of the pharmacist professional includes providing orientation to patients (pharmaceutical care) concerning the possibility of developing dependence on the medications used. It is important to emphasize that these medications, used in isolation, are unable to treat dependence where there is always the need for follow-up or nonpharmacological intervention (NIDA, 2007). The utilized medications are controlled by Ordinance No. 344/98 and belong to the classes of narcotics (A1), psychotropics (B1) or "other medications subject to special control" (C1). These include: bupropion, methadone, buprenorfine, naltrexone, disulfiram, acamprosate (Brasil, 1998).

- Behavioral therapy: this helps in the engagement of dependent individuals, modifying their attitudes and behaviors in the event of stressing circumstances, environments of consumption and compulsion. This therapy extends the length of time individuals remain in treatment and raises the effectiveness of medication treatment and includes: Cognitive Behavioral Therapy, Motivational Interviews and Group Therapy (NIDA, 2007).

Some investigations have demonstrated that the participation of a pharmacist professional in these stages of treatment of dependent patients was extremely satisfactory, particularly when related to medication dispensation and pharmacovigilance of them. In Ireland and England, the presence of a pharmacist professional was essential in the follow-up of patients making use of methadone to treat for heroin dependence. Ranking among the most important activities, are those related to damage reduction, in which the pharmacist professionals helps in the injection of medication, controls the needles and the amount of medication administered, besides exercising greater control of medication and better follow-up of patient treatment (Fleming et al., 2001; Roberts, Hunter, 2004).

Additionally, pharmacist professionals could act in Pharmaceutical Care, promoting information on the correct form of administration of antidepressive and anxiolytic agents, or by applying follow-up protocols for patients in use of medications whose history could help the multidisciplinary team accompanying these patients or simply by promoting Pharmacovigilance. In term of the multidisciplinary team, the pharmacist could help this team by providing these other professionals with knowledge on drugs' mechanisms of action, toxicokinetics, dynamics, pharmacological interaction and adverse reactions. Besides this activity, pharmacist professionals could even help in the choice of pharmacotherapy and avoid possible erroneous use of medications. They could also act by clarifying the information regarding the processes of detoxification of patients for a particular drug, or on abstinence crises and interactions in the event of overdose in patients (Dole, Tommasello, 2002).

\section{Toxicological analyses}

It is known that analytical toxicology deals with the detection of chemical agents or parameters related to toxicant exposition, with the purpose of preventing or diagnosing intoxications. In this context, toxicological analysis is a safe conduct to identify the exposition to drugs, irrespective of the characteristics in connection with the type of consumption, because the currently used methods present sufficient sensitivity and specificity to identify, in biological samples, the psychoactive substances present in drugs and/or their biotransformation products (Bass, Vamvakas, 2000; Silva, Tawil, 2008).

According to Decree No. 85878, of April $7^{\text {th }}, 1981$, one of the duties of the pharmacist professional is the 
performing of functions, assistance and technical responsibility in "organs, laboratories, sectors of pharmaceutical establishments in which quality control and/or inspection are developed, previous analysis, control analysis and fiscal analysis of products having therapeutic or anesthetic nature, or that are diagnosis auxiliaries, or able to determine physical or psychic dependence". In addition to these functions, in Article $2^{\text {nd }}$ there are some duties inherent to professionals which are not private, the most relevant of these being "organs and laboratories or establishments in which examinations of chemical-toxicological character are developed..." (Brasil, 1981).

Today, pharmacist professionals do not act only in toxicological analyses. In clinical toxicology, for instance, they are also involved in a great number of medical practices. The increase of such professionals in these services helps, besides other activities, in the creation of health policies against drug abuse, pharmacovigilance and poisoning (Chyka, 2007). Toxicological analysis could be considered yet another area of action for pharmacist professionals wishing to work in this context. The duties of pharmacist professional include helping in the diagnosis and monitoring of dependent patients' treatment.

\section{FINAL CONSIDERATIONS}

Ultimately, pharmacist professionals are responsible for choosing their own vocation within the profession, but as healthcare professionals they have a duty to acquire basic knowledge on drug abuse and dependence. This is because for these professionals, contact, even if minimal, with the population, albeit within commercial establishments exercising technical responsibility, universities conducting investigations and training new professionals, or even in hospitals and laboratories where clinical and toxicological analyses are performed, places them in a privileged position of adviser, confidant and guide.

The pharmacist professional has to be prepared in order to deal with different psychosocial issues of drug abuse and dependence, and to exercise their professional role as a health agent. To this end, investigations into the development of this human resource should be carried out and specialization courses for the different types of professional action in this area should be stimulated, aiming at future placement of more pharmacist professionals into multidisciplinary health teams, who can intervene in the health-disease process of dependent individuals and contribute to the development of increasingly effective prevention programs in the national milieu.

\section{REFERENCES}

ALMEIDA, M. G.; LIMA, I. V. Barbitúricos e benzodiazepínicos. In: OGA, S.; CAMARGO, M. M. A; BATISTUZZO, J. A. O. (Eds.). Fundamentos de toxicologia. 3.ed. São Paulo: Atheneu Editora, 2008. p.375-388.

AMERICAN PSYCHATRIC ASSOCIATION. DSM IV. 4.ed. Diagnostic and statistical manual of mental disorder. Washington: American Psychatric Association, 1994. 886 p.

ANDRADE, A. G.; QUEIROZ, S.; VILLABOIM, R. C. M.; CÉSAR, C. L. G.; ALVES, M. C. G. P.; BASSIT, A. Z. Uso de álcool e drogas entre alunos de graduação da Universidade de São Paulo. Rev. ABP-APAL., v.19, n.2, p.53-59, 1997.

BASS, R.; VAMVAKAS, S. The toxicology expert: what is required? Toxicol. Lett., v.112-113, p.383-389, 2000.

BRASIL. Decreto n ${ }^{\circ} 85.878$, de 7 de abril de 1981. Ministério da Saúde. Estabelece normas para execução da Lei 3.820, de 11 de novembro de 1960, sobre o exercício da profissão farmacêutica e dá outras providências. Diário Oficial da União, Brasília, DF, 9 abr. 1981. Seção 1, p.76-78.

BRASIL. Lei $\mathrm{n}^{\circ} 11.343$, de 23 de agosto de 2006. Institui o Sistema Nacional de Políticas públicas sobre Drogas; prescreve medidas para prevenção de uso indevido, atenção e reinserção social de usuários e dependentes de drogas; estabelece normas para repressão à produção não autorizada e ao tráfico ilícito de drogas; define crimes e dá outras providências. Diário Oficial da União, Brasília, DF, 24 agosto 2006. Seção 1, p.2-7.

BRASIL. Ministério da Saúde. Secretaria Executiva. Coordenação Nacional de DST/Aids. A Política do Ministério da Saúde para atenção integral a usuários de álcool e outras drogas / Ministério da Saúde, Secretaria Executiva, Coordenação Nacional de DST e Aids. Brasília: Ministério da Saúde, 2003. 6 p. (Série B, Textos Básicos de Saúde).

BRASIL. Portaria 344, de 12 de maio de 1998. Agência Nacional de Vigilância Sanitária. Aprova o Regulamento Técnico sobre substâncias e medicamentos sujeitos a controle especial. Diário Oficial da União, Brasília, DF, 01 fevereiro 1999. Seção 1, p.69-92. 
BRASIL. Resolução nº 27, de 30 de março de 2007b. Agência Nacional de Vigilância Sanitária Dispõe sobre o Sistema Nacional de Gerenciamento de Produtos Controlados - SNGPC, estabelece a implantação de módulos para drogarias e farmácias e dá outras providências. Diário Oficial da União, Brasília, DF, 02 abr. 2007. Seção 1, p.62-64.

BRASIL. Resolução n ${ }^{\circ}$ 417, de 29 de setembro de 2004. Conselho Federal de Farmácia. Aprova o Código de Ética da profissão Farmacêutica. Diário Oficial da União, Brasília, DF, 17 novembro 2004. Seção 1, p.306-307.

BRASIL. Secretaria Nacional Antidrogas. I Levantamento Nacional sobre os padrões de consumo de álcool na população brasileira. Brasília, DF: Secretaria Nacional Antidrogas. 2007a. 76 p.

BUSTO, U.; KNIGHT, K.; JANECEK, E.; ISAAC, P.; PARKER, $\mathrm{K}$. A problem-based learning course for pharmacy students on alcohol and psychoactive substance abuse disorders. Am. J. Pharm. Educ., v.58, n.1, p.55-60, 1994.

CARLINI, E. A. II Levantamento domiciliar sobre o uso de drogas psicotrópicas no Brasil: estudo envolvendo as 108 maiores cidades do país: 2005. São Paulo: Centro Brasileiro de Informação sobre Drogas Psicotrópicas/UFESP, 2006. $468 \mathrm{p}$.

CARLINI, E. A.; NAPPO, S. A. The pharmacovigilance of psychoative medications in Brazil. Rev. Bras. Psiquiatr., v.25, n.4, p.200-205, 2003.

CARLINI-CONTRIM, B.; GAZAL-CARVALHO, C.; GOUVEIRA, N. Comportamento de saúde entre jovens estudantes das redes públicas e privadas da área metropolitana do Estado de São Paulo. Rev. Saúde Pública, v.34, n.6, p.636-645, 2004.

CAZENAVE, S. O. S.; COSTA, J. L. Alucinógenos. In: OGA, S.; CAMARGO, M. M. A.; BATISTUZZO, J. A. O. (Eds.). Fundamentos de toxicologia. 3.ed. São Paulo: Atheneu Editora, 2008. p.465-480.

CHASIN, A. A. M.; SILVA, E. S.; CARVAlHO, V. M. Estimulantes do sistema nervoso central. In: OGA, S.; CAMARGO, M. M. A.; BATISTUZZO, J. A. O., (Eds.). Fundamentos de toxicologia. 3.ed. São Paulo: Atheneu Editora, 2008. p.353-374.
CHYKA, P. A. Pharmacists as clinical toxicologists: reflections on evolution, challenges, and opportunities. Ann. Pharmacother., v. 41, n.10, p.1708-1711, 2007.

DOLE, E. J.; TOMMASELLO, A. Recommendations for implementig effective substance abuse education in pharmacy pratice. In: HAACK, M. R.; ADGER, H. (Eds.). Strategic plan for interdisciplinary faculty development: arming the nation health professional workforce for a new approach to substance use disorders. Providence, Rhoad Island: Association for Medical Education and Research in Substance Abuse, 2002. p.263-273.

FLEMING, G. F; MCELNAY, J. C.; HUGHES, C. M.; SHERIDAN, J.; STRANG, J. The role of the community pharmacist in drug abuse: a comparison of service provision between Northern Ireland and England. Wales. Pharm. World Sci., v.23, n.1, p.13-16, 2001.

GALDURÓZ, J. C. F.; NOTO, A. R.; NAPPO, S. A.; CARLINI, E. A. Household survey on drug abuse in Brazil: Study involving the 107 major cities of the country -2001. Addict. Behav., v.30, n.3, p.545-565, 2005.

GALVÃO, J. F.; GALVÃO, T. F.; MOREAU, R. L. M. Tabaco. In: OGA, S.; CAMARGO, M. M. A.; BATISTUZZO, J. A. O. (Eds.). Fundamentos de toxicologia. 3.ed. São Paulo: Atheneu Editora, 2008. p.419-432.

GRAHAN, A.; PFEIFER, M.; TRUMBLE, J.; NELSON, E. D. A pilot project:continuing education for pharmacists on substance abuse prevention. Subst. Abus., v.20, n.1, p.3343, 1999.

KOOB, G. F.; AHMED, S. H.; BOUTREL, B.; CHEN, S. A.; KENNY, P. J.; MARKOU, A.; O’DELL, L. E.; PARSONS, L. H.; SANNA, P. P. Neurobiological mechanisms in transition from drug use to drug dependence. Neurosci. Biobehav. Rev., v.27, n.8, p.79-749, 2004.

MACHADO, A. R.; MIRANDA, P. S. C. Fragmentos da história de atenção à saúde para usuários de álcool e outras drogas no Brasil: da Justiça à Saúde Pública. Hist. Cienc. SaudeManguinhos, v.14, n.3, p.801-821, 2007.

MOREAU, R. L. M. Cannabis. In: OGA, S.; CAMARGO, M. M. A.; BATISTUZZO, J. A. O. (Eds.). Fundamentos de toxicologia. 3.ed. São Paulo: Atheneu Editora, 2008. p.433-446. 
MOREAU, R. L. M. Fármacos e Drogas que Causam Dependência. In: OGA, S.; CAMARGO, M. M. A.; BATISTUZZO, J.A. O. (Eds.). Fundamentos de toxicologia. 3.ed. São Paulo: Atheneu Editora, 2008. p.325-336.

NATIONAL INSTITUTE ON DRUG ABUSE. NIH. Publication $\mathrm{n}^{\circ}$ 07-5605, printed in apr. 2007. Drugs, Brains, and Behavior: The Science of Addiction. Available at: <www. drugabuse.gov>. Accessed on: 19 aug. 2008.

O'BRIEN, C. P. Drogação e uso abusivo de drogas. In: GOODMAN, L. S.; GILMAN, A. G. (Eds.). As bases farmacológicas da terapêutica. 11.ed. Rio de Janeiro: MacGraw-Hill Interamericana do Brasil, 2006. p.543-562.

OLIVEIRA, G. H.; CAMARGO, M. M. A. Opiáceos e Opióides. In: OGA, S.; CAMARGO, M. M. A.; BATISTUZZO, J. A. O. (Eds.). Fundamentos de yoxicologia. 3.ed. São Paulo: Atheneu Editora, 2008. p.337-352.

ORGANIZAÇÃO MUNDIAL DE SAÚDE. Reagindo aos problemas de drogas e do álcool na comunidade. São Paulo: Livraria Santos Editora, 1992. 246 p.

PEPE, V. L. E.; CASTRO, C. G. S. O. A interação entre prescritores, dispensadores e pacientes: informação compartilhada como possível benefício terapêutico. Cad. Saude Publica, v.16, n.3, p.815-822, 2000.

ROBERTS, K.; HUNTER, C. A compreensive system of pharmaceutical care drug misusers. Harm. Reduct. J., v.1, 2004. Available at: $<$ http://harmreductionjoyurnal.com. conect/1/1/6>.Accessed on: 1 aug. 2008.

SCIVOLETTO, S.; MALBERGIER, A.; PILEGGI, A. Etanol. In: OGA, S.; CAMARGO, M. M. A.; BATISTUZZO, J. A. O. (Eds.). Fundamentos de toxicologia. 3. ed. São Paulo: Atheneu Editora, 2008. p.389-404.
SILVA, O.A.; TAWIL, N. Monitorização da farmacodependência. In: MOREAU R. L. M.; SIQUEIRA M. E. P. B. (Eds.). Toxicologia analítica. Rio de Janeiro: Guanabara Koogan Editora, 2008. p.100-108.

STEMPLIUK, V. A.; BARROSO, L. P.; ANDRADE, A. G.; NICASTRI; S.; MALBERGIER, A. Comparative study of drug use among undergraduate students at the University of São Paulo. São Paulo campus in 1996 and 2001. Rev. Bras. Psiquiat., v.2, n.3, 2005. p.185-193.

TOMASELLO, A. C. Substance abuse and pharmacy practice: what the community pharmacists needs to know about drug abuse and dependence. Harm. Reduct. J., v.1, n.3, 2004. p.1-15.

WAGNER, G. A.; ANDRADE, A. G. Uso de álcool, tabaco e outras drogas entre estudantes universitários brasileiros. Rev. Psiquiat. Clin., v.35, supl.1, p.45-48, 2008.

WAGNER, G. A.; STEMPLIUK, V. A.; ZILBERMAN, M. L.; BARROSO, L. P.; ANDRADE, A. G. Alcohol and drug use among university students: gender differences. Rev. Bras. Psiquiatr., v.29, n.2, p.123-129, 2007.

WORLD DRUG REPORT 2007. Genebra: United Nations Office on Drug and Crime, 2007. 274 p.

Received for publication on $13^{\text {th }}$ August 2008 Accepted for publication on $16^{\text {th }}$ June 2009 